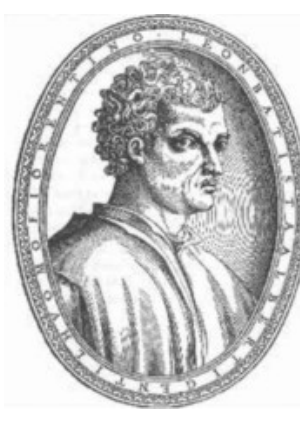

\title{
Exhibit Review \\ L'uomo del Rinascimento. Leon Battista Alberti e le Arti a Firenze tra Ragione e Bellezza
}

\author{
Palazzo Strozzi, Florence, 11 March - 23 August 2006 \\ http://www.albertiefirenze.it \\ Reviewed by Marcello Scalzo \\ Università degli Studi di Firenze \\ Dipartimento di Progettazione dell'Architettura \\ 50132 Florence ITALY \\ oycsca@tin.it \\ keywords: Leon Battista Alberti, Palazzo Strozzi, Renaissance \\ architecture, beauty
}

Il nocciolo, a cui l'olivo aveva chiesto quando avrebbe dato i suoi frutti, dal momento che fioriva con il freddo, rispose: "Quando sarà tempo"

(The seed, when asked by the olive tree when it would produce fruit, replied: "When the time is right")

\section{B. Alberti, Apologhi Centum, XXXIV}

Ever since the celebrations of Leon Battista Alberti's death in 1972 and, more precisely, since the Mantua exhibit in Palazzo del Te in 1994, studies on Alberti have been increasingly flourishing and successful, both in quantity (number of conferences and workshops), and in quality, thanks to the progress in our knowledge. The founding of the Fondazione Centro Studi Leon Battista Alberti in Mantua in 1998 strengthened the common focus of a group of researchers towards the cultural rediscovery of Humanism, understood as the consciousness of the determinant presence of man during the course of history; perhaps inspired by a hopeful desire of its renewal in the modern cultural context, frozen in the search of an identity that combines (ir) rationality and beauty.

This idea appears to be the main theme of the exhibit currently presented at the Palazzo Strozzi in Florence, organized by Cristina Acidini Luchinat, Superintendent of the Opificio delle Pietre Dure of Florence, and Gabriele Morolli, professor of history of architecture at the Architecture Faculty of the University of Florence.

The exhibit itinerary, which flows through an elegantly designed setting, starts with the genealogy and family origins of Alberti, and continues through his literary and scientific formation, his treatises on painting and architecture, his writings on technical and mathematical topics, his literary writings, and his architectural works.

Nexus Network Journal 8 (2006) 119-122

NEXUS NETWORK JOURNAL - VOL. 8, NO. 2, 2006119 1590-5896/06/020119-3 DOI 10.1007/s00004-006-0025-7

(C) 2006 Kim Williams Books, Firenze 
The works are presented from a standpoint that constantly refers to the city of Florence and the Florentine clients, and emphasizes a critical examination of the (ethical) aesthetics of Alberti. There is a web of references and works by other authors derived from - or merely influenced by - Alberti's thought, in order to show how much he infused the artistic vision of what would soon become the Renaissance. Alberti's aesthetic cannot be understood if detached from the moral, political, scientific and pedagogical context upon which he founded his particular classicist culture, but he also understood how, with surprising far-sightedness, to relate to the reality of the late Middle Ages in order to be able to convey it to true Humanism.

La bellezza è l'armonia tra tutte le membra, nell'unità di cui fan parte, fondata sopra una legge precisa, per modo che non si possa aggiungere o togliere o cambiare nulla se non in peggio (Beauty is that reasoned harmony of all the parts within a body so that nothing can be added, taken away or altered, but for the worse) L. B. Alberti, De re aedificatoria.

Alberti, literate and erudite, emerges from the Florentine Renaissance in which the main protagonists were magistri, craftsmen, luxury artisans. Albert was far from being a omo sanza lettere, as Leonardo used to describe himself.

More than in the scholarly presentation of the Alberti's architecture, the value of this exhibit lies in the release of some new biographical documentation on the Alberti family, a family whose gloomy presence constantly shadowed Leon Battista in his never-ending exile, not so much from Florence as from his own people.

Besides the family papers and the literary writings, the exhibit displays works by artists who were contemporaries of Alberti's, in order to show the complete cultural scene of Florence in the Quattrocento.

The exhibit itinerary - from architecture, paintings, drawings, models, book chapters - shows Alberti as a man often misunderstood in his own epoch, in which he is repeatedly considered as a theoretician rather than as a magistro, working master, while at the same time he is revealed to be a person of deep intuition about the reality of the future, based on a knowledge of the past. Alberti is like a seed that blossoms after the dormancy of winter, and especially in his preparation of the ground for the time when fruit would mature.

Sure enough, among the fruits that we may still pick today from the whole Renaissance legacy of the Florentine Quattrocento, both material and hidden within the architectural design process, the exhibit staging could not have been designed without using a proportional system based on the Florentine braccio, as the didactic captions explain to the unprivileged and unlearned visitor, unable to perceive in the exhibit itinerary the underlying harmony of measures and spaces.

The exhibited works are many, all extremely valuable and precious, but not all directly related to the theme of the exhibit and not all worthy such a high-level

120 MarCello SCALZO- Review of L'uomo del Rinsacimento. Leon Battista Alberti... 
cultural event. There are some inexactitudes and gross generalizations (not a mention of Laurana, the presumed author of the famous painting La Città Ideale!) but of course the average visitor does not notice these. This kind of exhibit is intended for the casual tourist, almost always a foreigner, who will find in the rooms of Palazzo Strozzi a summa of the Florentine Renaissance, complemented by effective didactic panels (who reads any more?), many images, a suggestive atmosphere, multimedia movies - spectacular but not always rational - a proud display of professionalism, erudition and technique.

The big exhibits, the big events, the big numbers: these are the cultural abc's to which we are all entitled.

Translated from Italian by Sylvie Duvernoy

\section{About the author}

Marcello Scalzo is an architect. He earned his Ph.D. at the University of Florence, discussing a dissertation on the study of the Rotonda by Brunelleschi in Florence, starting from a drawing by Giuliano da Sangallo. He currently teaches techniques of architectural representation and measured surveying at the architecture faculty of the University of Florence. Besides being a specialist in Italian Renaissance architecture, he has also inquired intothe characteristics of rock architecture (Architettura rupestre) of southern Italy. He is the author of numerous papers published in international journals and in the proceedings of international meetings. 
